\title{
Water use by a groundwater dependent maize in a semi-arid region of Inner Mongolia: Evapotranspiration partitioning and capillary rise
}

\author{
Yao $\mathrm{Wu}^{\mathrm{a}}$, Tingxi Liu ${ }^{\mathrm{a}, *}$, Paula Paredes ${ }^{\mathrm{b}}$, Limin Duan ${ }^{\mathrm{a}}$, Luis S. Pereira ${ }^{\mathrm{b}}$ \\ a College of Water Conservancy and Civil Engineering, Inner Mongolia Agricultural University, Hohhot 010018, China \\ ${ }^{\mathrm{b}}$ LEAF - Landscape, Environment, Agriculture and Food, Institute of Agronomy, University of Lisbon, Tapada da Ajuda, 1349-017 Lisbon, Portugal
}

\section{A R T I C L E I N F O}

\section{Article history:}

Received 22 September 2014

Accepted 20 January 2015

Available online 11 February 2015

\section{Keywords:}

SIMDualKc model

Groundwater contribution

Dual crop coefficients

Crop transpiration

Soil evaporation

Groundwater dependent ecosystems

\begin{abstract}
A B S T R A C T
This study aimed at assessing the soil water balance, groundwater contribution, crop transpiration and soil evaporation of a rainfed maize crop in Horqin sandy area, north-eastern Inner Mongolia, China. Two years of field data from the Agula site were used, 2008 with relatively high rainfall (363 mm) and high water table, and 2009 with low rainfall $(125 \mathrm{~mm})$ and lower water table. The SIMDualKc water balance model was calibrated with observed soil water content data of 2008 and validated with data of 2009. The model uses the dual crop coefficient approach for evapotranspiration (ET) partitioning, and parametric functions for computing capillary rise. The respective modelling results show that the groundwater contribution represented ca. 50\% of crop ET in both years. Estimation errors are small, with root mean square errors of 0.007 and $0.008 \mathrm{~cm}^{3} \mathrm{~cm}^{-3}$ respectively in 2008 and 2009 . The Nash and Sutcliffe modelling efficiency were high, 0.93 in both years, which indicates a low variance of residuals. The calibrated basal crop coefficient $K_{\mathrm{cb} \text { mid }}=0.95$ denotes a low density of the crop because it is much lower than common potential values. Soil evaporation was relatively low, $23 \%$ of ET in the wet year and $17 \%$ in the dry year, because capillary rise does not contribute to soil evaporation but to roots extraction only. Results show that capillary rise plays a main role in supplying the vegetation throughout the season, hence a strong dependence of vegetation upon groundwater.
\end{abstract}

(C) 2015 Elsevier B.V. All rights reserved.

\section{Introduction}

The Horqin sandy land (hereafter Horqin) is the largest of the four sandy lands with active dunes of Inner Mongolia. It has an area of $12,500 \mathrm{~km}^{2}$ and is located in eastern Inner Mongolia. It is an ecologically fragile area, where wind erosion is very active (Li et al., 2004) and the process of desertification is important (Zhao et al., 2006). These sandy land areas are unique eco-systems considering climate, geo-hydrological conditions, physical geography and land and water use (Duan et al., 2011a).

Research has been developed in Horqin relative to the ecohydrological processes and their relations with vegetation and soil (Duan et al., 2011a,b; Zhao et al., 2009; Zuo et al., 2009). The vegetation in Horqin consists of pioneer species in the mobile sandy dunes, shrubs and herbaceous vegetation in semi-fixed and fixed sandy dunes, forests in sandy soils of lowlands, and croplands and grasslands in more flat lands with sandy loam soils. Vegetation ecotypes vary with soil moisture and depth of the shallow groundwater

\footnotetext{
* Corresponding author. Tel.: +86 13947116156.

E-mail addresses: wuyao.will@163.com (Y.Wu), txliu1966@163.com (T. Liu).
}

(Ma and Liu, 2007; Shi et al., 2007). Zheng et al. (2012) assessed the importance of groundwater for various types of vegetation and the role of vegetation types on groundwater decline. However, the observations of the time variability of the soil water content at various soil depths and for diverse vegetation types were not followed by an adequate soil water balance. Therefore, despite the recognized importance of soil water and groundwater for the various vegetation types, knowledge on the various components of the water balance and estimates of the shallow groundwater contribution (GWC) to evapotranspiration (ET) are lacking.

Zhang et al. (2009) observed that farmland expansion is a major cause of steppe loss in northern China. In Horqin farmland is increasing with an average annual rate of $1.03 \%$, mainly replacing steppe grassland by maize. Bagan et al. (2010) reported that the area of cropland doubled over the last three decades. In parallel, other studies refer the decline of the shallow groundwater associated with land use changes, including irrigated crops (Zhang and Zhao, 2003; Zhao et al., 2009; Zheng et al., 2012). In Horqin, maize water use studies refer only to irrigation (Li et al., 2003; Tang et al., 2011). No studies have been performed on rainfed maize supplied by shallow groundwater. Therefore, there is the need for better understanding the processes relative to water use 
by a groundwater-fed maize crop, thus performing a water balance study focused on the role of the shallow groundwater and on the crop evapotranspiration dynamics.

The importance of shallow groundwater for sustaining vegetation has been assessed in several water balance studies with lysimeters that evidenced the dependency of various ecosystems and crop systems from shallow groundwater (Kahlown et al., 2005; Kowalik, 2006; Gowing et al., 2009; Liu and Luo, 2011). However, models were not used in these studies. Differently, various deterministic models have been used to assess the GWC by simulating the upward fluxes from the water table, e.g., RZWQM (Stulina et al., 2005), WAVE (Liu et al., 2006), HYDRUS-1D (Soylu et al., 2011), and SWAP (Xu et al., 2013). Stochastic approaches were reported, among others, by Vervoort and Van der Zee (2008) and Tamea et al. (2009). Models referred above are able to produce good estimates of GWC but may be highly exigent in terms of soil water data, and require appropriate observation of the soil water content and of the soil water potential for their calibration and testing. Differently, when using a soil water balance model only the basic soil hydraulic properties are required and the model may be calibrated using only soil water content observation data. This is the case of the approach developed by Liu et al. (2006) that derived from the WAVE model a set of parametric equations for simulating upward and downward fluxes through the bottom of the root zone of a cropped soil. These parametric equations were then integrated in the water balance model ISAREG that produced good estimates of crop ET in presence of shallow water tables (Pereira et al., 2007; Cholpankulov et al., 2008). Those parametric equations are presently integrated in the water balance model SIMDualKc, formerly tested with a maize crop in presence of a shallow water table (Rosa et al., 2012b).

The SIMDualKc (Rosa et al., 2012a) is not only able to simulate water use by a crop in presence of a shallow water table, but has also the advantage of partitioning crop ET $\left(\mathrm{ET}_{\mathrm{c}}\right)$ into actual crop transpiration $\left(T_{\mathrm{a}}\right)$ and soil evaporation $\left(E_{\mathrm{S}}\right)$ using the dual crop coefficient approach proposed in FAO56 (Allen et al., 1998). Modelling using this approach or for the quantification of the groundwater contribution to ET has not been applied in Inner Mongolia. Therefore, considering the importance of better understanding crop water use in the fragile Horqin sand land and, in particular, the need for improved knowledge on the interactions between vegetation and shallow groundwater, that may support a better policy on water and landscape management in Horqin, the objectives of this study consist of: (a) calibration and validation of the SIMDualKc model to assess water use components of rainfed maize; (b) evaluating the groundwater contribution to crop ET; and (c) assessing impacts of changes in water table levels on the dynamics of maize water use, transpiration, soil evaporation and groundwater contribution.

\section{Materials and methods}

\subsection{Site and crop characteristics}

The study area is located in the southern Horqin sandy area $\left(43^{\circ} 18^{\prime} 48^{\prime \prime}\right.$ to $43^{\circ} 21^{\prime} 24^{\prime \prime} \mathrm{N}, 122^{\circ} 33^{\prime} 00^{\prime \prime}$ to $122^{\circ} 41^{\prime} 00^{\prime \prime} \mathrm{E}$ ), in the Agula eco-hydrological study area, eastern Inner Mongolia (Fig. 1). As mapped in Fig. 1, the main vegetation type between dunes is presently cropland followed by grassland meadows, groundwaterfed (Duan et al., 2011a). The dunes have various types of shrubs vegetation. The cropland is mainly occupied with maize; other crops are sunflower, black beans and millet. The maize farm field used in this study was located within a large maize crop area.

The climate is semi-arid continental with cold and dry winter; according to the Köppen classification, the climate is a Bsk, cold arid steppe (Kottek et al., 2006). The average annual precipitation is $389 \mathrm{~mm}$, which mainly occurs during the summer monsoon. The temperature varies from $-13^{\circ} \mathrm{C}$ in January to $24^{\circ} \mathrm{C}$ in July (Duan et al., 2011a). An automatic meteorological station is installed at about $200 \mathrm{~m}$ from the maize study site. Observed weather data included precipitation $(\mathrm{mm})$, air temperature $\left({ }^{\circ} \mathrm{C}\right)$, relative humidity (\%), wind speed $\left(\mathrm{m} \mathrm{s}^{-1}\right)$ with the anemometer installed at $2 \mathrm{~m}$

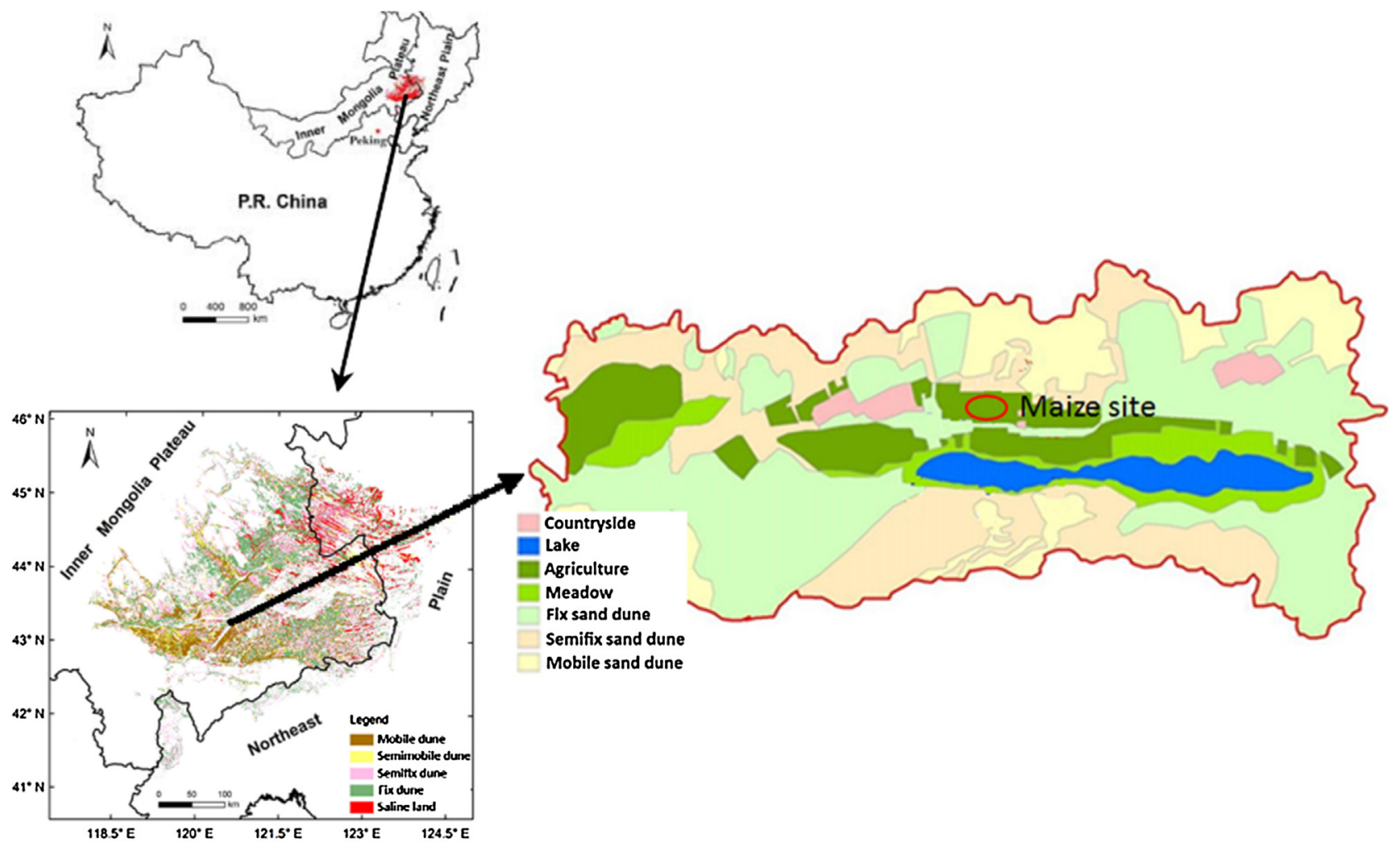

Fig. 1. Location of the study area, land use map and location of the study site. 
above ground, and sunshine duration $(\mathrm{h})$. These data were used to compute the reference evapotranspiration $\left(\mathrm{ET}_{0}, \mathrm{~mm} \mathrm{~d}^{-1}\right)$ using the FAO-PM method (Allen et al., 1998).

The climate in the area is dry and windy. Minimum relative humidity data for both crop seasons of 2008 and 2009 show that atmospheric dryness was particularly important by the spring and late summer (Fig. 2a). Wind speed was also higher during the same periods (Fig. 2b). During summer, due to monsoon effects, air humidity is higher and wind speed is lower. Thus, because $\mathrm{ET}_{0}$ is highly influenced by the atmospheric dryness and high wind speed, the highest $\mathrm{ET}_{\mathrm{O}}$ values (Fig. 2c) were observed during spring and late summer, thus out of the rainy periods. Considering the maize crop season, $\mathrm{ET}_{0}$ was higher during the drier year of 2009 and precipitation (Fig. 2c) was much higher in 2008 than in 2009, thus the study was performed under contrasting climate conditions.

The soil is a sandy loam which main soil hydraulic properties are summarized in Table 1 . The soil water content (SWC, $\mathrm{cm}^{3} \mathrm{~cm}^{-3}$ ) was surveyed with a neutron probe previously calibrated for a wide range of soil water data; measurements were performed with five-day intervals and three replications. Readings were performed for every $0.10 \mathrm{~m}$ until the water table depth. Limitations of SWC observations using neutron probes are discussed by Allen et al. (2011) relative to soil data acquisition requirements and accuracy, which were satisfied in the current study relative to ET estimation.

The groundwater depth was observed every 5-10 days at a well installed in the centre of the field using a water level transducer. Results in Fig. 3 show that in 2008 precipitation was enough abundant to percolate to the water table and keep it high. On the contrary, precipitation in 2009 was insufficient and the water table declined throughout the crop season due to plant roots extraction.

Spring maize (Zea mays var. Zhengdan 958) was planted by 10 th of May on both years and harvested by 1st and 5th October, respectively in 2008 and 2009. Table 2 presents the dates of the crop growth stages for both experimental years. Main differences in lengths of crop stages relate to climate conditions.

Plant density was 52,500 plants ha ${ }^{-1}$. No irrigation was applied. Plant height $(h, \mathrm{~m})$, leaf area index (LAI) and fraction of ground cover $\left(f_{\mathrm{c}}\right)$ were surveyed in a $1 \mathrm{~m}^{2}$ sample area every 10 days; surveys included observations of the effective root depth $\left(Z_{\mathrm{r}}, \mathrm{m}\right)$, which did not exceed $0.70 \mathrm{~m}$. Thus, modelling was developed considering a root depth of $0.70 \mathrm{~m}$. Results for crop height and root depths are given in Table 3 and the $f_{\mathrm{c}}$ curves are shown in Fig. 4.
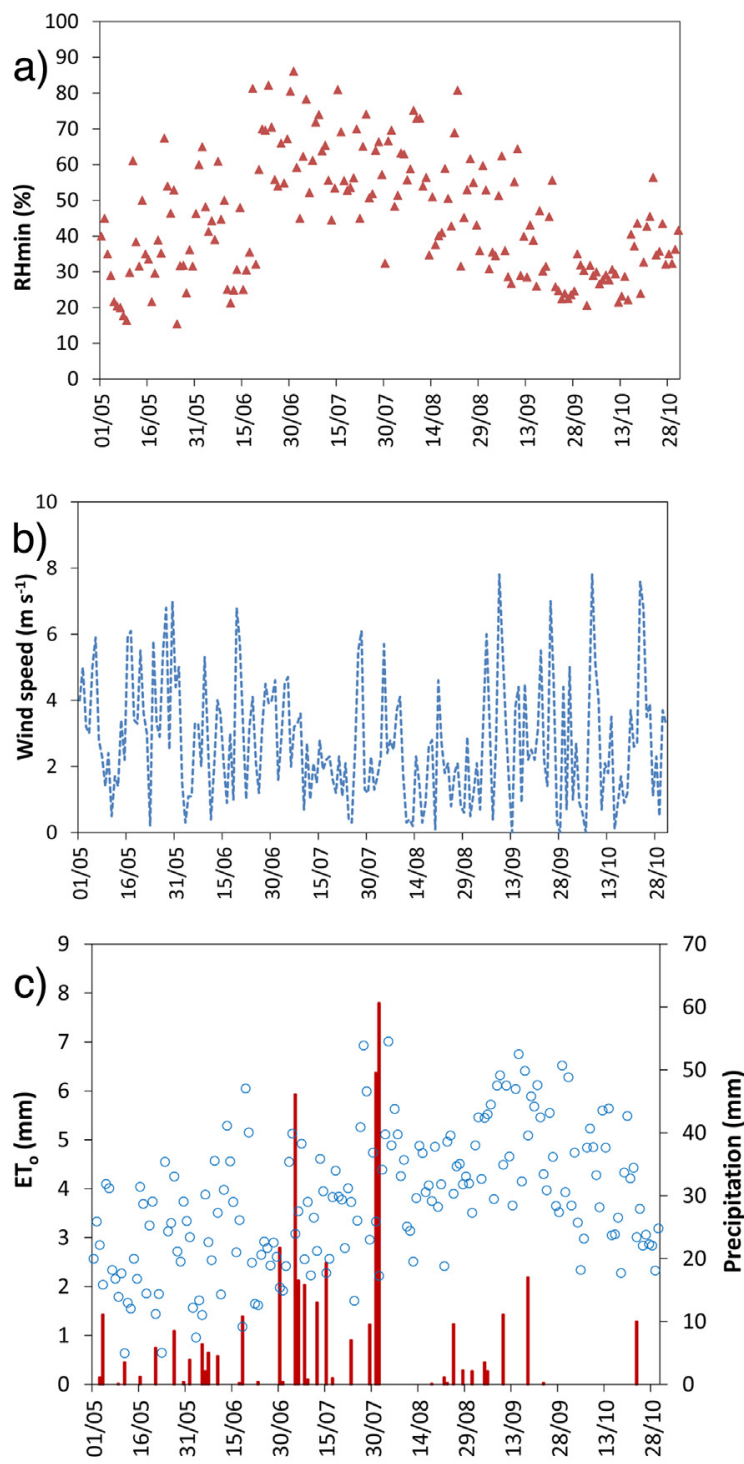
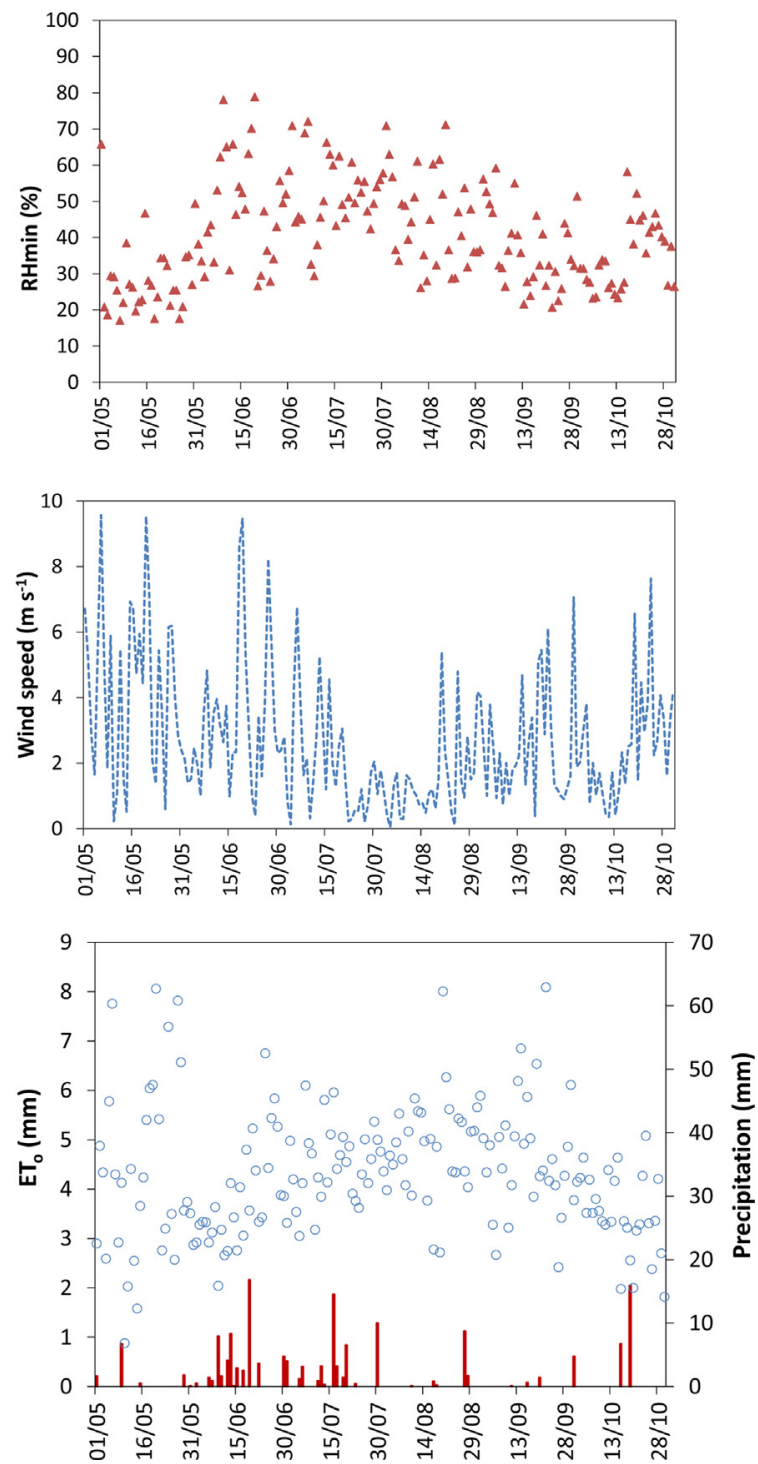

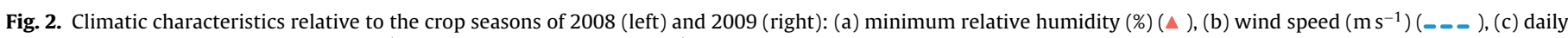
reference evapotranspiration $\left(\mathrm{ET}_{0}, \mathrm{~mm} \mathrm{~d}^{-1}\right)(\mathrm{O})$ and precipitation $\left(\mathrm{mm} \mathrm{d}^{-1}\right)(\mathbb{})$. 
Table 1

Soil hydraulic properties of the Agula maize site.

\begin{tabular}{|c|c|c|c|c|}
\hline Layer & Depth (cm) & Layer thickness $(\mathrm{cm})$ & Field capacity $\left(\mathrm{cm}^{3} \mathrm{~cm}^{-3}\right)$ & Wilting point $\left(\mathrm{cm}^{3} \mathrm{~cm}^{-3}\right)$ \\
\hline 1 & $0-30$ & 30 & 0.22 & 0.08 \\
\hline 2 & $30-90$ & 60 & 0.20 & 0.07 \\
\hline
\end{tabular}

Table 2

Dates of the maize growth stages for each season.

\begin{tabular}{|c|c|c|c|c|}
\hline \multirow[t]{2}{*}{ Season } & \multicolumn{4}{|c|}{ Crop growth stages } \\
\hline & Initial & Rapid growth & Mid-season & Late-season \\
\hline 2008 & 10 May-09 June & 10 June- 14 July & 15 July-08 September & 09 September-01 October \\
\hline 2009 & 10 May-19 June & 20 June-19 July & 20 July-09 September & 10 September-05 October \\
\hline
\end{tabular}

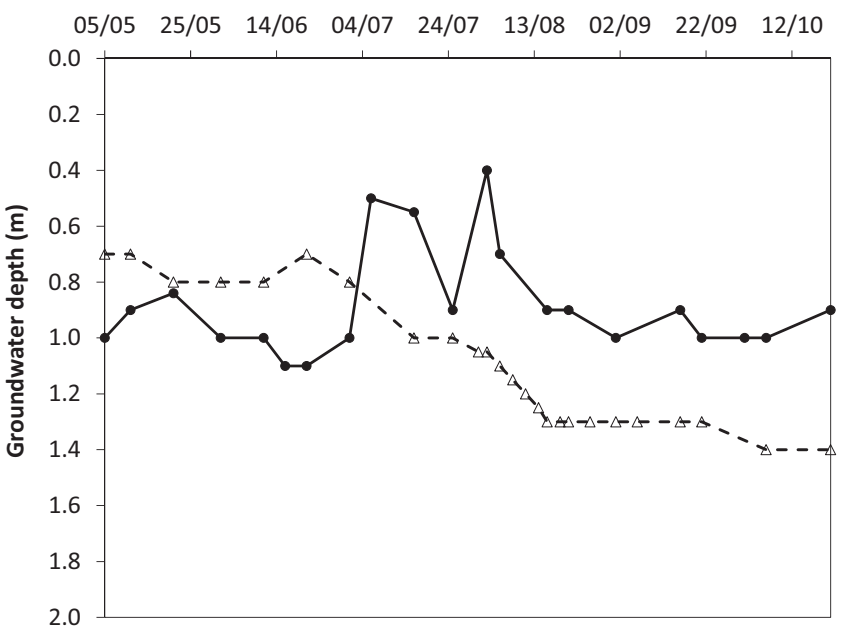

Fig. 3. Groundwater depth variation during the maize crop seasons of 2008 (-•-) and $2009(-\triangle-)$.

Table 3

Crop height $(\mathrm{h})$ and root depth $\left(Z_{\mathrm{r}}\right)$ throughout the crop growth stages.

\begin{tabular}{lllllll}
\hline & & Initiation & $\begin{array}{l}\text { Start rapid } \\
\text { growth }\end{array}$ & $\begin{array}{l}\text { Start } \\
\text { mid-season }\end{array}$ & $\begin{array}{l}\text { Start Late- } \\
\text { season }\end{array}$ & Harvest \\
\hline \multirow{2}{*}{2008} & $h(\mathrm{~m})$ & 0.01 & 0.50 & 1.70 & 1.95 & 1.90 \\
& $Z_{\mathrm{r}}(\mathrm{m})$ & 0.20 & 0.25 & 0.70 & 0.70 & 0.70 \\
2009 & $h(\mathrm{~m})$ & 0.01 & 0.50 & 1.65 & 1.85 & 1.80 \\
& $Z_{\mathrm{r}}(\mathrm{m})$ & 0.20 & 0.30 & 0.70 & 0.70 & 0.70 \\
\hline
\end{tabular}

\subsection{SIMDualKc model}

The SIMDualKc model (Rosa et al., 2012a) performs the soil water balance at field scale with a daily time step. For evapotranspiration computations, it applies the dual crop coefficient approach (Allen et al., 1998, 2005), thus partitioning $\mathrm{ET}_{\mathrm{c}}$ into soil evaporation $\left(E_{\mathrm{s}}\right)$, and actual crop transpiration $\left(T_{\mathrm{a}}\right)$. The model has been previously calibrated and validated for maize in presence of a shallow water table in Portugal (Rosa et al., 2012b), for monsoon conditions in the North China Plain (Zhao et al., 2013), and for sprinkler and trickle irrigation in Brazil and Portugal (Martins et al., 2013; Paredes et al., 2014). The partition of $\mathrm{ET}_{\mathrm{c}}$ was tested in previous studies, namely for soil evaporation by Zhao et al. (2013) and for transpiration by Paço et al. (2014).

The daily soil water balance of the root zone may be described as:

$D_{r, i}=D_{r, i-1}-(P-R O)_{i}-I_{i}-C R_{i}+\mathrm{ET}_{\mathrm{c}, i}+\mathrm{DP}_{i}$

where $D_{r, i}$ and $D_{r, i-1}$ are the root zone depletion [mm] at the end of day $i$ and $i-1$, respectively, $P_{i}$ is precipitation, $R O_{i}$ is runoff, $I_{i}$ is net irrigation depth, $C R_{i}$ is capillary rise from the groundwater table, $\mathrm{ET}_{\mathrm{c}, i}$ is crop evapotranspiration, and $\mathrm{DP}_{i}$ is deep percolation, all referring to day $i$ expressed in $\mathrm{mm}$. In this application $I_{i}=0$ because the crop was not irrigated and $R O_{i}=0$ because the land is flat and runoff was not observed. The model outputs consist of the daily terms of the soil water balance, thus ET, net irrigation, crop transpiration, soil evaporation, deep percolation and groundwater contribution.

When the SWC in the root zone falls below the soil water threshold $S W C_{p}$ corresponding to the depletion fraction for no stress $(\mathrm{p})$, i.e., $S W C<S W C_{p}$, then the actual evapotranspiration $\left(E_{c} T_{c a t}\right)$ is smaller than $\mathrm{ET}_{\mathrm{c}}$ and is estimated as:

$\mathrm{ET}_{\mathrm{c} \mathrm{act}}=\left(K_{\mathrm{s}} K_{\mathrm{cb}}+K_{\mathrm{e}}\right) \mathrm{ET}_{\mathrm{o}}$

where $\mathrm{ET}_{\mathrm{c} \text { act }}$ is the actual crop ET $\left(\mathrm{mmd}^{-1}\right), K_{\mathrm{cb}}$ is the basal crop coefficient, $K_{\mathrm{e}}$ is the soil evaporation coefficient, $K_{\mathrm{s}}$ is the water stress reduction coefficient, and $\mathrm{ET}_{0}$ is the reference evapotranspiration $\left(\mathrm{mm} \mathrm{d}^{-1}\right) . K_{\mathrm{s}}$ is computed daily from comparing the
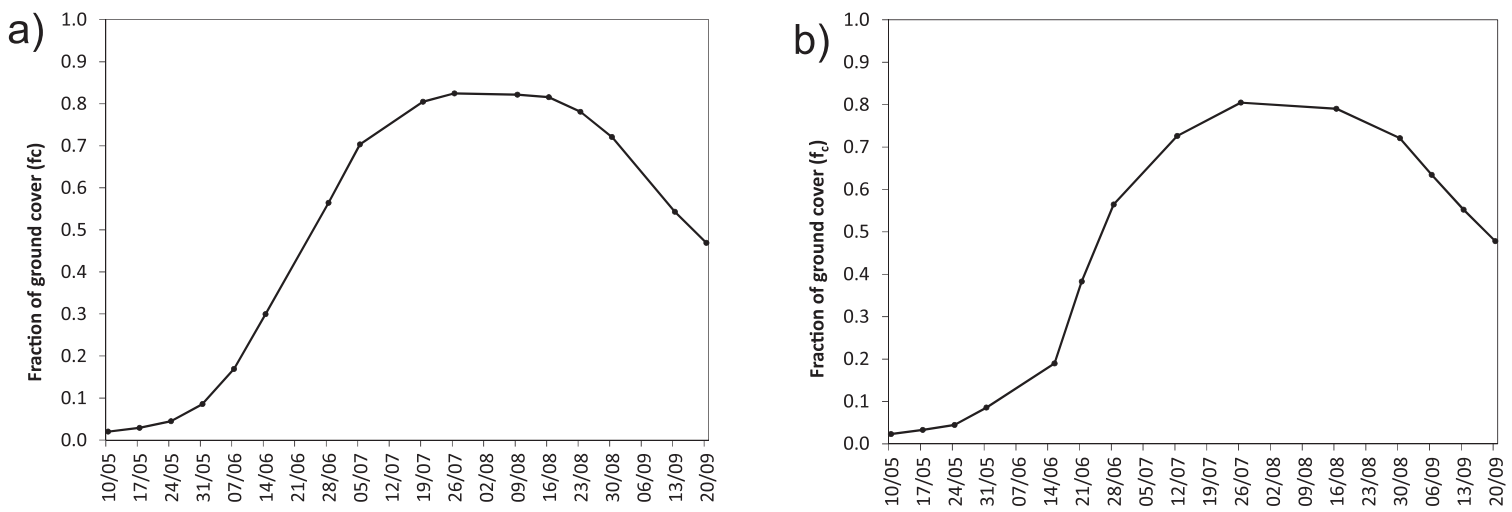

Fig. 4. Seasonal variation of the fraction of ground cover $\left(f_{c}\right)$ along the crop seasons of 2008 (a) and 2009 (b). 
available soil water with $S W C_{p}$, thus $K_{s}=1.0$ if $S W C \geq S W C_{p}$, otherwise $K_{\mathrm{s}}<1.0$ depending upon the water deficit in the soil (Allen et al., 1998; Rosa et al., 2012a). The product $K_{\mathrm{s}} K_{\mathrm{cb}}$ represents the actual $K_{\mathrm{cb}}$ relative to the actual soil water and environmental conditions $\left(K_{\mathrm{cb} \text { act }}\right)$. Thus, the actual crop transpiration is $T_{\mathrm{a}}=K_{\mathrm{s}} K_{\mathrm{cb}} \mathrm{ET}_{\mathrm{o}}$ and soil evaporation is $E_{\mathrm{S}}=K_{\mathrm{e}} \mathrm{ET}_{\mathrm{O}}$.

$K_{\mathrm{cb}}$ and $p$ are input parameters that are submitted to calibration. The input $K_{\mathrm{cb}}$ is adjusted to climate conditions (minimum relative humidity and wind speed) following Allen et al. (1998) and to crop density as a function of the fraction of ground covered by the crop $\left(f_{\mathrm{c}}\right.$, Fig. 3$)$ and crop height $(h$, Table 3$)$ using the procedure proposed by Allen and Pereira (2009).

$K_{\mathrm{e}}$ is computed after a daily water balance of the evaporative layer of the soil, taking into consideration $f_{\mathrm{c}}$ and the evaporative characteristics of the soil (Allen et al., 1998, 2005; Rosa et al., 2012a). The two-phases Ritchie's model (Ritchie, 1972) is used, which assumes a first phase where evaporation is energy limited and a second phase where evaporation is limited by the available soil water. The cumulated evaporation at the end of the first phase is named readily evaporable water (REW, $\mathrm{mm}$ ), while that attained at the end of the second phase is the total evaporable water (TEW, $\mathrm{mm}$ ). REW and TEW, as well as the thickness of the evaporative layer $\left(Z_{\mathrm{e}}, \mathrm{m}\right)$, are object of calibration and depend upon the soil hydraulic properties (Allen et al., 1998, 2005). Further descriptions of the model are provided by Rosa et al. (2012a).

The parametric equations used for estimation of the daily capillary rise and deep percolation fluxes are those proposed by Liu et al. (2006). The actual CR fluxes $\left(\mathrm{mm} \mathrm{d}^{-1}\right)$ are estimated using data on the actual water table depth $\left(D_{\mathrm{w}}, \mathrm{m}\right)$, actual soil water storage $\left(W_{\mathrm{a}}, \mathrm{mm}\right)$, potential evapotranspiration $\left(\mathrm{ET}_{\mathrm{c}}, \mathrm{mm} \mathrm{d}^{-1}\right)$ and potential (maximum) capillary rise $\left(\mathrm{CR}_{\max }, \mathrm{mm} \mathrm{d}^{-1}\right)$. The actual daily CR flux is computed proportionally to $\mathrm{CR}_{\max }$ depending upon $\mathrm{ET}_{\mathrm{c}}, D_{\mathrm{w}}$ and $W_{\mathrm{a}}(\mathrm{mm})$. CR reduces relative to $\mathrm{CR}_{\max }$ when the root zone storage $W_{\mathrm{a}}$ is high, or the depth $D_{\mathrm{w}}$ of the water table increases, and/or $\mathrm{ET}_{\mathrm{c}}$ decreases. The parameters relative to water storage $\left(a_{1}, b_{1}, a_{2}, b_{2}\right)$, to the relationships between $D_{\mathrm{w}}$ and $\mathrm{ET}_{\mathrm{c}}$ $\left(a_{3}, b_{3}\right)$, and to the $\mathrm{CR}_{\max }$ calculation $\left(a_{4}, b_{4}\right)$ have to be calibrated taking into consideration the local soil and water table characteristics (Liu et al., 2006). Sets of parameter values for silty, silt loam and sandy loam soils were proposed by Liu et al. (2006), which may be used as default values to initiate the parameters' calibration. The DP flux $\left(\mathrm{mm} \mathrm{d}^{-1}\right)$ is computed using a time decay function relating the soil water storage near saturation with the time after the occurrence of a heavy rain or irrigation (Liu et al., 2006). The corresponding parameters $\left(a_{\mathrm{D}}, b_{\mathrm{D}}\right)$ also need to be calibrated.

The input data required by SIMDualKc consists of:

(a) Meteorological daily data on precipitation and reference evapotranspiration $\mathrm{ET}_{0}$, minimum relative humidity $\left(\mathrm{RH}_{\mathrm{min}}, \%\right)$, and wind speed at $2 \mathrm{~m}$ height $\left(u_{2}, \mathrm{~m} \mathrm{~s}^{-1}\right)$.

(b) Soil water content data at field capacity and wilting point for the various soil layers of the root zone (Table 1 ).

(c) Crop data on dates of crop growth stages - initial, crop development, mid-season, late season and end season (Table 2); basal crop coefficients $\left(K_{\mathrm{cb}}\right)$ and soil water depletion fractions for non-stress ( $p$ ) for the initial, mid-season and end-season stages, which need to be calibrated; root depths $\left(Z_{\mathrm{r}}, \mathrm{m}\right)$, plant height $(h, \mathrm{~m})$ and fraction of ground cover $\left(f_{\mathrm{c}}\right)$ along the crop season (Table 3 and Fig. 4).

(d) Soil evaporation data on REW and TEW (mm), and depth $Z_{\mathrm{e}}$ [m] of the evaporable layer as defined above, which require calibration.

(e) Groundwater contribution and deep percolation data relative to water table depths (Fig. 3) and LAI values at various dates along the crop season, and the CR and DP parameters previously mentioned, that require calibration.

When used for irrigation, the model requires data on irrigation depths and dates, or relative to various irrigation options. If runoff is likely to occur, the curve number CN (Allen et al., 2007) is required for computing RO (mm).

\subsection{Model calibration, validation and performance assessment}

Simulation of annual crops starts on the day of planting and restarts at the planting day every year. The model is initialized every year of the crop season with selected/calibrated parameters and for that initial day, with an estimated/observed initial value of the soil water content and of the water table depth. The parameters used to initialize the model consist of the initial (default) set when starting with the calibration, or the calibrated set when performing validation or using the model in any application study or practice, e.g., simulating alternative water management options.

The calibration procedure of the SIMDualKc model aims at obtaining crop parameters ( $K_{\mathrm{cb}}$ and $p$ for each crop growth stage), soil evaporation parameters ( $Z_{\mathrm{e}}$, TEW and REW) and CR and DP parameters (as described before) that minimize the differences between observed and simulated soil water content in the entire root zone. As for other referred SIMDualKc applications (e.g., Rosa et al., 2012b; Martins et al., 2013; Zhao et al., 2013; Paredes et al., 2014), the calibration procedure started by selecting an initial set of crop, soil evaporation, CR and DP parameters that correspond to the characteristics of the crop and soil under consideration. An iterative trial and error search procedure (T\&E) was developed aimed at progressively reducing the residual errors of simulation. The T\&E procedure was used to first search for improved values for $K_{\mathrm{cb}}$ and $p$. When errors became small, T\&E was applied to the CR and DP parameters until an acceptable match of observed and simulated SWC values was obtained along with reduced errors. Then the procedure was applied to the soil evaporation parameters and later to refine the estimation of the $K_{\mathrm{cb}}$ values.

The calibration was performed with data of 2008 and the validation, using the previously calibrated parameters, with data of 2009. Two years of data provide for two independent data sets, one for calibration and the other for validation. The adequateness of calibrating and validating SIMDualKc with only two years data was discussed by Martins et al. (2013) in light of recommendations by Sinclair and Seligman (2000) on crop models. Abi Saab et al. (2015) have shown that calibrating a crop water model for any among three years of observations led to similar model performance, which supports using one year for calibration and the second for validation. In addition, recommendations about data requirements (Allen et al., 2011) were fulfilled and the model calibration was initiated with adequate default parameters as previously analyzed (Rosa et al., 2012b). Two years of data were therefore considered sufficient in this application, particularly taking into consideration that these two years had contrasting climate and water table depths (Figs. 2c and 3), thus allowing to assess maize water use and groundwater contribution for a wider range of observed data.

To assess the goodness-of-fit of the modelling approach several indicators were selected as applied and defined in former studies (Rosa et al., 2012b; Martins et al., 2013; Zhao et al., 2013). The following goodness-of-fit indicators were adopted:

(a) The parameters of the linear regression forced through the origin relating observed and simulated SWC data, i.e., the corresponding regression coefficient $(b)$ and determination coefficient $\left(R^{2}\right)$. $b$ close to 1 means that the predicted values are statistically similar to the observed ones, and $R^{2}$ close to 
1.0 indicates that most of the variance of the observed values is explained by the model.

(b) The root mean square error (RMSE), the average absolute error $(A A E)$, the average relative error (ARE), and the maximum error $\left(E_{\max }\right)$, which are statistical measures of the estimation errors (units as for the variable under fitting).

(c) The modelling efficiency (EF, non-dimensional), proposed by Nash and Sutcliffe (1970), that determines the relative magnitude of the residual variance compared to the measured data variance. EF close to 1.0 indicates that the variance of residuals is much smaller than the measured data variance, contrarily when $\mathrm{EF}$ is $\leq \mathbf{0}$ (Moriasi et al., 2007).

(d) The Willmott (1981) index of agreement ( $d_{\mathrm{IA}}$, nondimensional), that represents the ratio between the mean square error and the "potential error". $d_{\mathrm{IA}}=1.0$ indicates perfect agreement and $d_{\mathrm{IA}}=0$ indicates no agreement at all between the observed and predicted values (Moriasi et al., 2007).

\section{Results and discussion}

\subsection{Model calibration and validation}

As described above, the calibration of the SIMDualKc model for rainfed spring maize was performed by minimizing the differences between observed and simulated SWC data from 2008 crop season while the validation was performed with 2009 data. Results of comparing the observed and simulated SWC show no bias in the simulations (Fig. 5).

Table 4 shows the initial/default and calibrated parameters relative to the crop ( $K_{\mathrm{cb}}$ and $p$ ) and to soil evaporation (TEW, REW,
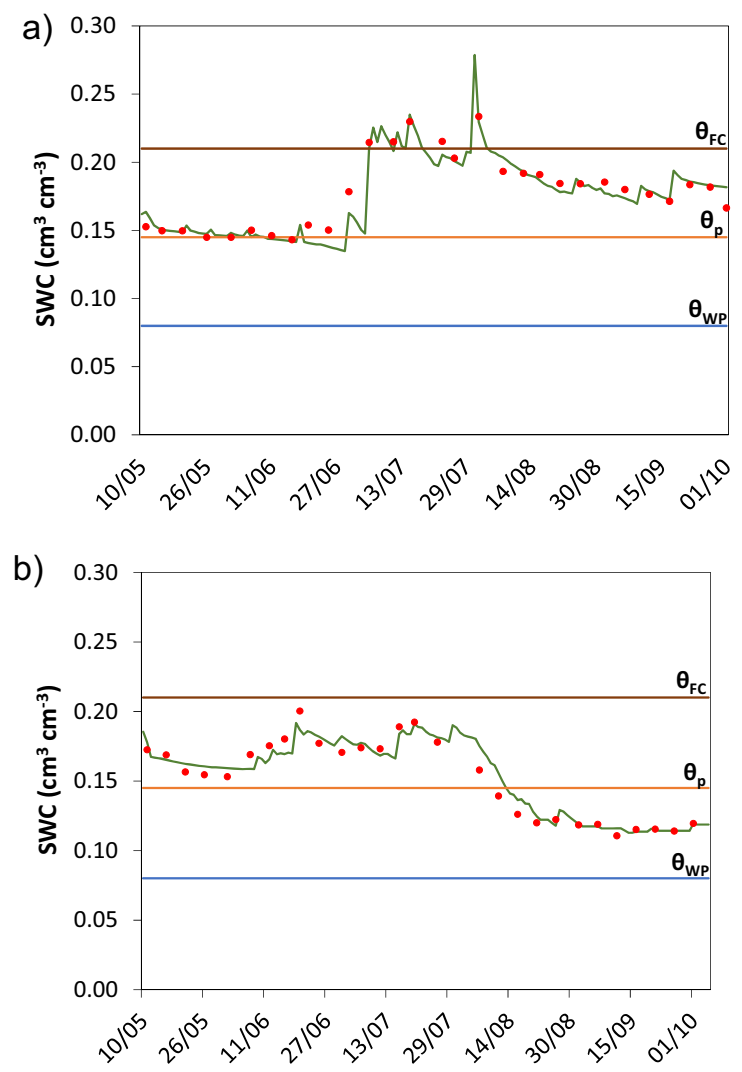

Fig. 5. Simulated and observed soil water content (SWC) for the rainfed maize crop in (a) 2008 (calibration) and (b) 2009 (validation). Lines $\theta_{\mathrm{FC}}, \theta_{\mathrm{WP}}$ and $\theta_{\mathrm{p}}$ refer to SWC at field capacity, wilting point and when depletion equals the depletion fraction for no stress, $p$.
$Z_{\mathrm{e}}$ ). The initial and calibrated $\mathrm{CR}$ and DP parameters are presented in Table 5. It can be observed that the initial sets of crop and soil evaporation parameters were close to the calibrated ones. Differences between initial and final values of the CR and DP parameters are not very large due to a good use of information proposed by Liu et al. (2006).

Table 6 presents the goodness of fit indicators when the model was used with calibrated and initial/default parameters (Tables 4 and 5). When using calibrated parameters, results show regression coefficients close to 1.0 and high determination coefficients of 0.93 for both the calibration and the validation. The variation of the observed values is therefore largely explained by the model. Errors of estimate are small, with RMSE of $0.007 \mathrm{~cm}^{3} \mathrm{~cm}^{-3}$ for the calibration and $0.008 \mathrm{~cm}^{3} \mathrm{~cm}^{-3}$ for the validation, while ARE did not exceed $4.0 \%$. The Nash and Sutcliffe EF are high, 0.93 for both the calibration and the validation, which indicates that the residuals variance is much smaller than the measured data variance, i.e., the model is a good predictor of the soil moisture dynamics. The Willmot indices of agreement are very high, 0.98 , thus indicating that the mean square error is quite close to the potential error due to modelling. Goodness-of-fit results indicate that SIMDualKc was appropriately calibrated and the parameter values may be used with confidence in further cropland studies in Horqin. Since parameters were obtained for two years having contrasting climate and water table depths, the applicability of the calibrated parameters is likely good.

Results using the default parameters are also presented in Table 6. They show that the model performance using default parameters were acceptable. This indicates that the model may be applied to conditions when data is insufficient for calibration as already noticed in previous applications (Rosa et al., 2012b). However results depend upon the appropriate selection of the default parameters.

\subsection{Crop coefficients}

The curves of the crop and evaporation coefficients $K_{\mathrm{cb}}, K_{\mathrm{cb}}$ act, $K_{\mathrm{c}}$ act and $K_{\mathrm{e}}$ (Eq. (2)) are presented in Fig. 6 together with the daily precipitation depths. $K_{\mathrm{cb}}$ values represented in Fig. 6 are slightly different from those in Table 4 because the latter are those used as input to the model, while those in Fig. 6 are already adjusted to climate and to crop density and height.

The actual basal crop coefficient $\left(K_{\mathrm{cb} \text { act }}\right)$ is below the potential $K_{\mathrm{cb}}$ curve (Fig. 6) for the initial period in both seasons because there was insufficient rain and the capillary rise was very small since roots were not yet developed and ET was very small. Therefore the crop was water stressed. CR increased only after roots developed and their distance to the water table became smaller. In 2008, the $K_{\mathrm{cb}}$ curve coincides with the potential one by the mid of the crop development stage (Fig. 6a) when there was enough rain to develop the maize crop and to rise the water table (Fig. 3). From there on both rainfall and CR were sufficient to sustain crop transpiration at its potential level and $K_{\mathrm{cb}}$ act was equal to the potential $K_{\mathrm{cb}}$. Differently, in 2009, maize was stressed from mid-season to harvesting because rain was insufficient and the watertable depth increased (Fig. 3), thus making CR also insufficient. Therefore, $K_{\mathrm{cb} \text { act }}<K_{\mathrm{cb}}$ during most of mid-season and the late season until harvesting (Fig. 6b).

The soil evaporation coefficient $\left(K_{\mathrm{e}}\right)$ was high during the initial stage in both seasons (Fig. 6), when $f_{\mathrm{c}}$ was small (Fig. 4) and a large fraction of soil was exposed to radiation, thus favouring soil water evaporation when the soil was wetted by rain. $K_{\mathrm{e}}$ decreased as the crop developed and the fraction $f_{\mathrm{c}}$ increased; thus $K_{\mathrm{e}}$ rapidly dropped and kept low during the mid-season. It slightly increased again by the end of the late season when leaf senescence occurred, $f_{\mathrm{c}}$ slightly decreased and more energy became available at the soil 
Table 4

The initial and calibrated basal crop coefficients $K_{\mathrm{cb}}, p$ depletion fractions for no stress and soil evaporation parameters.

\begin{tabular}{|c|c|c|c|c|c|c|c|c|c|}
\hline & \multicolumn{6}{|c|}{ Crop parameters } & \multicolumn{3}{|c|}{ Soil evaporation } \\
\hline & $K_{\text {cb ini }}$ & $K_{\mathrm{cb} \text { mid }}$ & $K_{\mathrm{cb} \text { end }}$ & $p_{\text {ini }}$ & $p_{\text {mid }}$ & $p_{\text {end }}$ & $Z_{\mathrm{e}}(\mathrm{m})$ & REW (mm) & TEW (mm) \\
\hline Initial/default & 0.15 & 1.15 & 0.30 & 0.55 & 0.55 & 0.55 & 0.10 & 8 & 15 \\
\hline Calibrated & 0.15 & 0.95 & 0.20 & 0.50 & 0.50 & 0.50 & 0.10 & 10 & 16 \\
\hline
\end{tabular}

Table 5

Initial and calibrated parameters of the capillary rise and deep percolation parametric equations.

\begin{tabular}{|c|c|c|c|c|c|c|c|c|c|c|}
\hline & \multicolumn{8}{|c|}{ Capillary rise } & \multicolumn{2}{|c|}{ Deep percolation } \\
\hline & $a_{1}$ & $b_{1}$ & $a_{2}$ & $b_{2}$ & $a_{3}$ & $b_{3}$ & $a_{4}$ & $b_{4}$ & $a_{\mathrm{D}}$ & $b_{\mathrm{D}}$ \\
\hline Initial values & 220 & -0.17 & 160 & -0.27 & -1.3 & 6.2 & 3.0 & -2.5 & 200 & -0.0173 \\
\hline Calibrated values & 320 & -0.17 & 270 & -0.27 & -1.3 & 6.2 & 3.0 & -2.5 & 230 & -0.02 \\
\hline
\end{tabular}

Table 6

Indicators of "goodness-of-fit" of the SIMDualKc model applied to groundwater fed maize when using calibrated and default parameters.

\begin{tabular}{|c|c|c|c|c|c|c|c|c|c|}
\hline Parameters & Crop season & $b$ & $R^{2}$ & $\operatorname{RMSE}\left(\mathrm{cm}^{3} \mathrm{~cm}^{-3}\right)$ & $\operatorname{AAE}\left(\mathrm{cm}^{3} \mathrm{~cm}^{-3}\right)$ & $\operatorname{ARE}(\%)$ & $I_{\max }\left(\mathrm{cm}^{3} \mathrm{~cm}^{-3}\right)$ & $\mathrm{EF}$ & $d_{\mathrm{IA}}$ \\
\hline \multirow[t]{2}{*}{ Calibrated } & 2008 & 0.99 & 0.93 & 0.007 & 0.006 & 3.2 & 0.016 & 0.93 & 0.98 \\
\hline & 2009 & 1.01 & 0.93 & 0.008 & 0.006 & 3.9 & 0.017 & 0.93 & 0.98 \\
\hline \multirow[t]{2}{*}{ Initial/default } & 2008 & 0.97 & 0.97 & 0.009 & 0.007 & 4.2 & 0.019 & 0.88 & 0.97 \\
\hline & 2009 & 0.91 & 0.87 & 0.018 & 0.016 & 10.5 & 0.031 & 0.61 & 0.90 \\
\hline
\end{tabular}

surface for evaporation. Differences between 2008 and 2009 are visible for $K_{\mathrm{e}}$ because, due to less and smaller wettings in 2009, soil evaporation was then smaller (Fig. 6b). To be noted that $K_{\mathrm{e}}$ is null when the crop was fed by capillary rise because CR does not supply moisture to the upper soil layer but only to roots extraction. Fig. 6 also shows the $K_{\mathrm{c}}$ act curve that represents the daily sum of $K_{\mathrm{cb} \text { act }}$ and $K_{\mathrm{e}}$. The daily $K_{\mathrm{c}}$ act curve shows a sequence of peaks due to soil
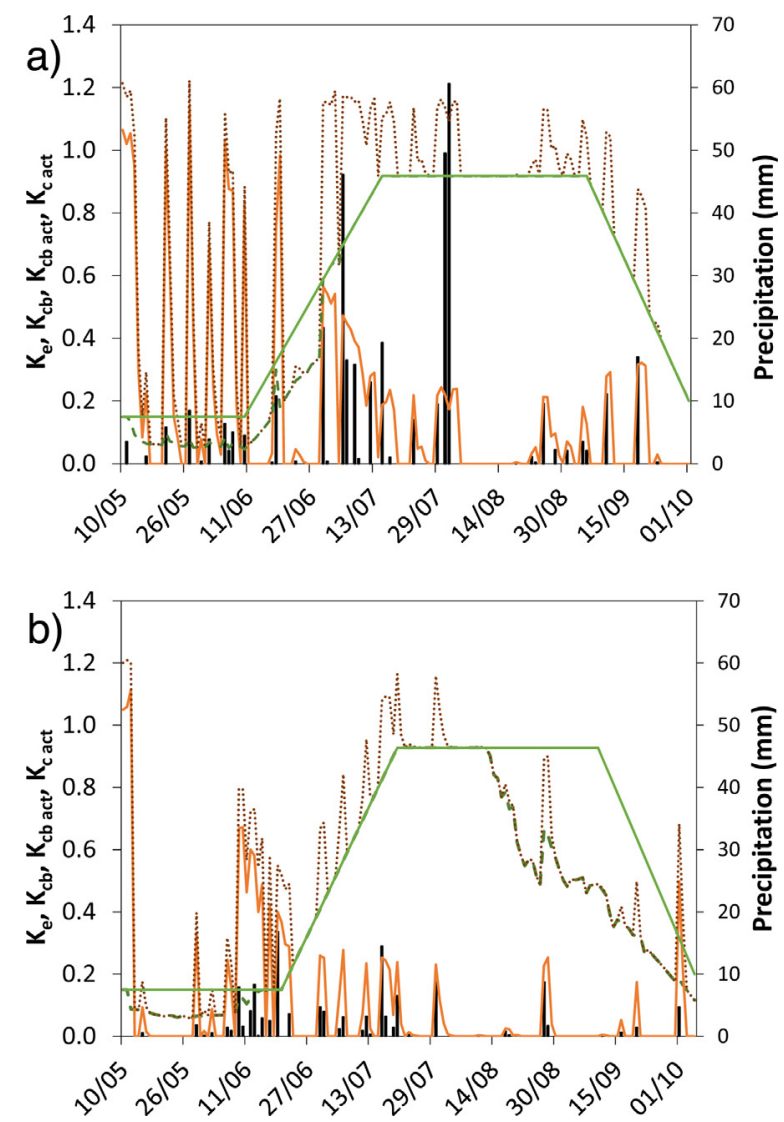

Fig. 6. $K_{\mathrm{cb}}(-), K_{\mathrm{cb} \text { act }}(--), K_{\mathrm{e}}(-)$, and $K_{\mathrm{c} \text { act }}(\ldots .$.$) ) curves as well as daily$ precipitation ( ) in the wet year of 2008 (a) and in the dry year of 2009 (b). evaporation when wetting events occur, thus being very different from the typical linear time averaged $K_{\mathrm{c}}$ curve proposed in FAO56 (Allen et al., 1998).

The $K_{\mathrm{cb} \text { ini }}$ and $p$ values are within those proposed by Allen et al (1998). However, the mid-season $K_{\mathrm{cb} \text { mid }}=0.95$ is lower than currently observed potential $K_{\mathrm{cb} \text { mid }}$ values for maize (e.g., Allen et al., 1998; Zhao et al., 2013). This is due to low planting density, that leads to low $f_{c}$, and to low crop height (Fig. 4 and Table 3). As analyzed by Allen and Pereira (2009), the $K_{\mathrm{cb}}$ and $K_{\mathrm{c}}$ values increase for dense and high crops. Low $K_{\mathrm{cb} \text { mid }}$ values were obtained with former maize varieties (e.g., Wright, 1982; Pereira et al., 2003). The resulting $K_{\mathrm{cb} \text { mid }}=0.95$ must therefore be considered as the potential value for a low density groundwater dependent maize crop adapted to Horqin area but not to be used when cropping for maximum yield. The $K_{\mathrm{cb} \text { end }}$ values are lower than usual due to leaves picking for animal fodder during late season, which is typical for maize cultivated as fodder crop in this region.

\subsection{Crop transpiration, soil evaporation and groundwater contribution}

The actual evapotranspiration computed by the model was 434 and $360 \mathrm{~mm}$ respectively in 2008 and 2009, and crop transpiration was then 333 and $300 \mathrm{~mm}$ respectively (Table 7). Differences between these years are due to contrasting rainfall and water table depths, where 2009 was a particularly dry year, causing quite heavy water stress from mid-season to harvest (Fig. 6b). The simulated soil evaporation was $23 \%$ and $17 \%$ of $\mathrm{ET}_{\mathrm{c}}$ act during the crop seasons of 2008 and 2009, respectively, with large soil wettings by rainfall in 2008 (Table 7). These results highly contrast with those reported by Zhao et al. (2013) for maize in the North China Plain, where soil evaporation was $37-45 \%$ of $\mathrm{ET}_{\mathrm{c}}$ act, hence about double that observed in Horqin area. This difference results from the fact that the maize crop referred by Zhao et al. (2013) was cropped under full supplemental irrigation and rainfall was much more abundant than in Horqin where the supply of crop transpiration was largely due to capillary rise (Fig. 7 and Table 7), which does not contribute to wet the upper soil evaporation layer.

Fig. 7 presents the daily simulated soil evaporation, actual crop transpiration and capillary rise together with the precipitation observed along both crop seasons. Main differences between 

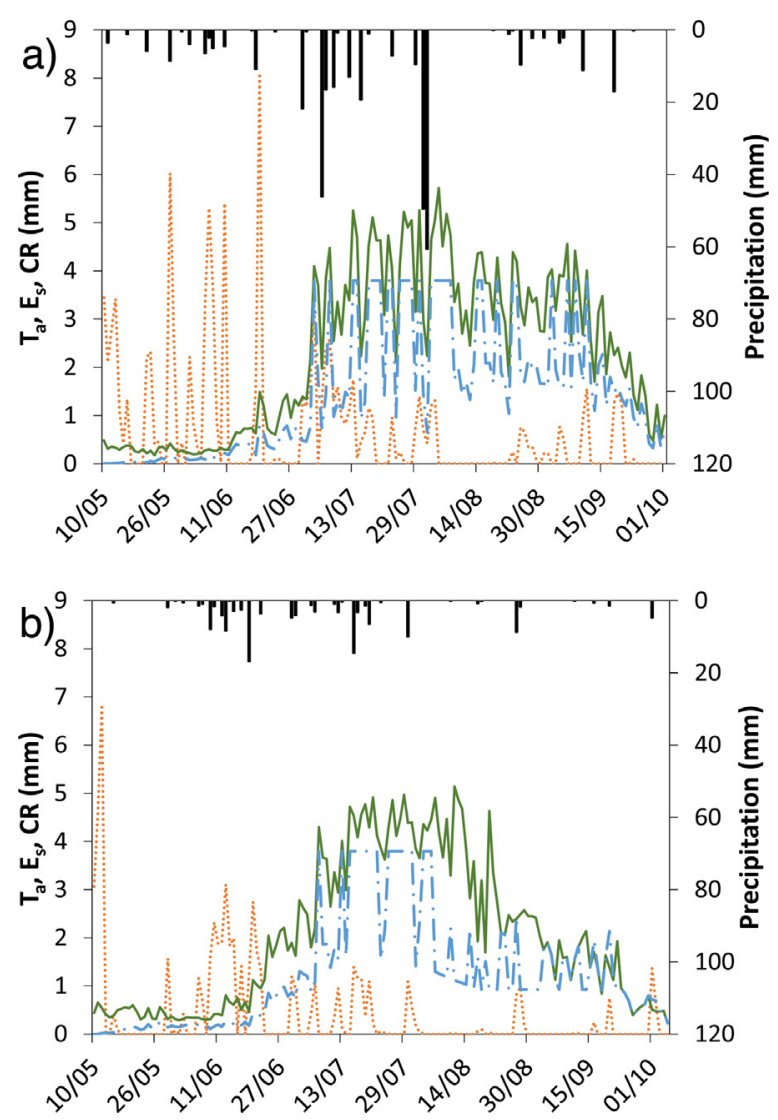

Fig. 7. Soil evaporation $\left(E_{\mathrm{s}}, \ldots \ldots\right)$, actual crop transpiration $\left(T_{\mathrm{a}}, \longrightarrow\right)$, and capillary rise (CR, - . ) fluxes, as well as precipitation ( ) during the crop seasons of 2008 (a) and 2009 (b).

seasons refer to rainfall, more abundant in 2008, and to the groundwater contribution since the water table was higher in 2008 (Fig. 3). The $E_{\mathrm{s}}$ peaks in the initial stage of the crop correspond to precipitation events, more abundant and larger in 2008. During this stage, soil evaporation was much larger than transpiration because the soil was not covered by vegetation ( $\operatorname{small} f_{\mathrm{c}}$ ) and radiation energy was highly available at the ground surface for evaporation. Results for $E_{\mathrm{s}}$ and $T_{\mathrm{a}}$ in Table 7 show that $E_{\mathrm{s}}$ accounted for $84 \%$ and $67 \%$ of actual evapotranspiration during the initial stage in 2008 and 2009, respectively. CR was then negligible (Fig. 7) because crop roots were not yet developed.

The size of $E_{\mathrm{s}}$ peaks decreased during the crop development stage. When the crop developed, transpiration rapidly increased and, because $f_{\mathrm{c}}$ increased (Fig. 4), less energy was available for soil evaporation. Thus, $E_{\mathrm{s}} / \mathrm{ET}_{\mathrm{c}}$ act reduced to $33 \%$ and $13 \%$ respectively in 2008 and 2009 (Table 7), with a smaller ratio in 2009 due to less rainfall events while transpiration became the main component of ET. During this crop development stage roots developed and capillary rise started increasing to attain maximum values by the mid-season stage. During mid-season, CR fluxes were smaller in 2008 because precipitation was large and extraction by roots was then predominantly from soil water.

In the mid-season stage CR kept high, thus becoming the main contributor to ET, essentially to $T_{\mathrm{a}}$. Naturally, the ratio $E_{\mathrm{s}} / \mathrm{ET}_{\mathrm{c}}$ act decreased to $7 \%$ and 3\% respectively in 2008 and 2009, when the crop fully developed and $\mathrm{f}_{\mathrm{c}}$ increased further. Those ratios are quite low because ET was mainly supplied by capillary rise, which does not contribute to $E_{s}$. During the late season, due to senescence of leaves and their picking for animal's fodder, $f_{\mathrm{c}}$ decreased together with transpiration resulting in an increase of the ratio $E_{\mathrm{s}} / \mathrm{ET}_{\mathrm{c} \text { act }}$, particularly in 2009 when the crop was highly stressed (Fig. 6b), and transpiration highly reduced (Table 7 ). Considering the crop season, results evidence that a higher $E_{\mathrm{S}} / \mathrm{ET}_{\mathrm{c}}$ act was observed in 2008 because precipitation events were larger and more frequent.

Differences between both years are evidenced during the midand late-season (Fig. 7). In the wet 2008, rainfall favoured crop vigour and contributed to raise the water table, thus to keep GWC high throughout that period. Differently, in the dry 2009, rainfall was insufficient and the water table steadily declined along the mid- and late-season. Hence the crop could not keep an appropriate rate of extraction of water from the water table. The evidence of water stress during that period is given by the decreasing $K_{\text {cb act }}$ curve shown in Fig. $6 \mathrm{~b}$ indicating that the crop progressively decreased transpiration while the upward fluxes from the water table also progressively decreased (Fig. 7b). At the lateseason the crop was maintained with groundwater contribution only, however quite reduced. Nevertheless, GWC in 2008 and 2009 represented similar fractions of the $\mathrm{ET}_{\mathrm{c}}$ act, respectively $50 \%$ and $51 \%$ (Table 8). These figures evidence the importance of GWC to crops in the Horqin sandy area.

\subsection{Soil water balance and groundwater contribution}

The monthly results of the soil water balance of the maize field show that precipitation in both years was insufficient to cover maize $\mathrm{ET}_{\mathrm{c} \text { act }}$ (Table 8), which evidences the role of groundwater contribution. GWC in 2008 was $216 \mathrm{~mm}$, which corresponds to $50 \%$ of $\mathrm{ET}_{\mathrm{c} \text { act }}$ of $436 \mathrm{~mm}$. Results were similar in 2009, where GWC was $185 \mathrm{~mm}$ corresponding to $51 \%$ of $\mathrm{ET}_{\mathrm{c} \text { act }}$ of $360 \mathrm{~mm}$. As referred before, differences in GWC relate to the water table level (Fig. 3), that was higher in 2008 during mid-season and late season, when crop roots were larger and crop $\mathrm{ET}_{\mathrm{c}}$ was higher, i.e., when conditions favoured higher capillary rise.

During the initial stage of the crop, by May, GWC was very low. In both years, it increased to $20 \%$ in June because $f_{\mathrm{c}}$ increased and roots developed. The largest values were observed for July, 76 and $85 \mathrm{~mm}$ respectively in 2008 and 2009, but corresponding to quite different percentages of $\mathrm{ET}_{\mathrm{c} \text { act }}$, respectively $53 \%$ and $67 \%$. This behaviour reflects the relatively abundant rain in 2008, when a large amount did percolate to the groundwater following the storms of July 31 and August 1, totaling $121 \mathrm{~mm}$. The lack of rain in August and September led to lowering the water table and to GWC much smaller in 2009 than in 2008.

Table 7

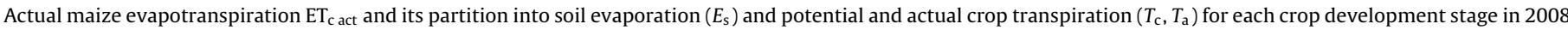
and 2009.

\begin{tabular}{|c|c|c|c|c|c|c|c|c|c|c|}
\hline \multirow[t]{2}{*}{ Crop growth stages } & \multicolumn{2}{|c|}{$E_{\mathrm{s}}(\mathrm{mm})$} & \multicolumn{2}{|c|}{$T_{\mathrm{c}}(\mathrm{mm})$} & \multicolumn{2}{|c|}{$T_{\mathrm{a}}(\mathrm{mm})$} & \multicolumn{2}{|c|}{$\mathrm{ET}_{\mathrm{c} \mathrm{act}}(\mathrm{mm})$} & \multicolumn{2}{|c|}{$E_{\mathrm{s}} / \mathrm{ET}_{\mathrm{c} \text { act }}(\%)$} \\
\hline & 2008 & 2009 & 2008 & 2009 & 2008 & 2009 & 2008 & 2009 & 2008 & 2009 \\
\hline Initial & 48 & 39 & 21 & 33 & 9 & 19 & 57 & 58 & 84 & 67 \\
\hline Crop development & 32 & 12 & 80 & 80 & 65 & 80 & 97 & 93 & 33 & 13 \\
\hline Mid-season & 15 & 5 & 201 & 207 & 201 & 172 & 216 & 177 & 7 & 3 \\
\hline Late season & 7 & 3 & 58 & 58 & 58 & 29 & 64 & 32 & 10 & 9 \\
\hline Full crop season & 102 & 60 & 360 & 379 & 333 & 300 & 434 & 360 & 23 & 17 \\
\hline
\end{tabular}


Table 8

Monthly soil water balance components for the maize crop seasons of 2008 and 2009.

\begin{tabular}{|c|c|c|c|c|c|c|c|c|c|}
\hline Period & & $P(\mathrm{~mm})$ & $\mathrm{ET}_{\mathrm{c} \text { act }}(\mathrm{mm})$ & $E_{\mathrm{s}}(\mathrm{mm})$ & $T_{\mathrm{a}}(\mathrm{mm})$ & $\mathrm{DP}(\mathrm{mm})$ & $\triangle \mathrm{SWC}(\mathrm{mm})$ & GWC (mm) & $\mathrm{GWC} / \mathrm{ET}_{\mathrm{c} \text { act }}(\%)$ \\
\hline \multirow[t]{6}{*}{2008} & May & 19 & 36 & 29 & 7 & 0 & 15 & 1 & 3 \\
\hline & June & 55 & 54 & 33 & 21 & 0 & -12 & 11 & 20 \\
\hline & July & 179 & 144 & 28 & 116 & 7 & -103 & 76 & 53 \\
\hline & August & 76 & 119 & 6 & 113 & $93^{\mathrm{a}}$ & 60 & 76 & 64 \\
\hline & September & 34 & 85 & 8 & 77 & 0 & 0 & 51 & 60 \\
\hline & Season & 363 & 434 & 102 & 333 & 100 & -41 & 216 & 50 \\
\hline \multirow[t]{6}{*}{2009} & May & 2 & 27 & 17 & 10 & 0 & 27 & 2 & 7 \\
\hline & June & 55 & 53 & 27 & 26 & 0 & -14 & 11 & 21 \\
\hline & July & 49 & 127 & 11 & 116 & 0 & -7 & 85 & 67 \\
\hline & August & 12 & 107 & 2 & 105 & 0 & 45 & 49 & 46 \\
\hline & September & 7 & 46 & 3 & 43 & 0 & 0 & 38 & 83 \\
\hline & Season & 125 & 360 & 60 & 300 & 0 & 47 & 185 & 51 \\
\hline
\end{tabular}

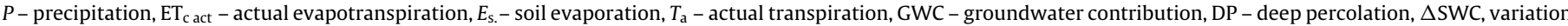
of the soil water content.

a This high percolation results from precipitations totaling $121 \mathrm{~mm}$ in days 31 July and 01 August.

The use of stored soil water ( $\Delta$ SWC) was relatively important in both years during the initial stage, in May, particularly in 2009 when rainfall was very low. Then, when monsoon rains start, SWC resulted increased at the end of June and July, particularly in 2008. The stored SWC was again contributing to ET in August but in September the variation of $\triangle$ SWC was null. By then GWC was quite important, representing $60 \%$ of $\mathrm{ET}_{\mathrm{c}}$ act, in 2008 and $83 \%$ in 2009, when soil water was largely depleted (Fig. 5b).

Results above show that cropping in Horqin and similar areas is only possible with groundwater contribution or with irrigation using pumped groundwater. However, irrigation will induce a progressive decline of the water table that will affect all natural and man-made ecosystems and will originate a progressive increase of irrigation requirements. Thus, in the following section impacts of alternative scenarios of groundwater depths are analyzed aiming at showing the consequences of groundwater withdrawal.

\subsection{Assessing impacts of alternative groundwater table depth scenarios}

Groundwater table depth variations are likely occurring and its decline is continuing (Zhao et al., 2009; Zheng et al., 2012; Yan et al., 2014). Therefore, several alternative groundwater table level (WTL) scenarios were simulated with the SIMDualKc model aimed at assessing related impacts on GWC and on water use by rainfed maize as cropped in Horqin. Scenarios were built upon the observations of 2008 (high rainfall and high water table) and 2009 (low rainfall and low water table) and consist of changing the WTL as follows:

WTL +10 - observed WTL increased by $10 \mathrm{~cm}$.

WTL -10 - observed WTL decreased by $10 \mathrm{~cm}$.

WTL - 20 - observed WTL decreased by $20 \mathrm{~cm}$.

Simulations were performed using all data observed in both years and the calibrated parameters, with the WTL data changed from observations as referred above. Results relative to groundwater contribution, $\mathrm{ET}_{\mathrm{c} \text { act }}$, crop transpiration and soil evaporation are presented in Table 9. For scenarios built from 2008 data, i.e., high rainfall and high WTL, changes in water table depth indicate small impacts on both $\mathrm{ET}_{\mathrm{c}}$ act and GWC because precipitation is enough to favour crop vigour and to recharge the groundwater. In other words, the condition relative to 2008 corresponds to a well balanced condition.

For scenarios built from 2009 data, i.e., with low rainfall and low water table, results show that WTL declining lead to a great decrease of GWC, from 185 to $115 \mathrm{~mm}$ when WTL is reduced by $10 \mathrm{~cm}$ and to $101 \mathrm{~mm}$ if a $20 \mathrm{~cm}$ lowering is considered (Table 9). Decreases of $\mathrm{ET}_{\mathrm{c}}$ act are also large, from 360 to $295 \mathrm{~mm}$ if the WTL lowers by $10 \mathrm{~cm}$ or to $283 \mathrm{~mm}$ if a $20 \mathrm{~cm}$ lowering is considered. Differences between results referring to 10 and $20 \mathrm{~cm}$ declining are small because the crop is already highly stressed with the present scenario and therefore results for both deficit scenarios reflect mainly the periods of August and September when stress is already high. The actual transpiration would decrease by 65 or $76 \mathrm{~mm}$ (Table 9) for the scenarios with WTL decreasing by 10 or $20 \mathrm{~cm}$ respectively, i.e., $22 \%$ and $25 \%$. These $T_{\mathrm{a}}$ decreases would produce high yield losses since yield is proportional to $T_{\mathrm{a}}$. Results agree with those presented by Xu et al. (2013). Soil evaporation remains unchanged because it depends only from rainfall and does not depend upon upward fluxes, which do not supply the evaporable soil layer. Differently, raising the water table by $10 \mathrm{~cm}$ in the dry year could have important benefits to $G W C$, resulting that $\mathrm{ET}_{\mathrm{C}}$ act and $T_{\mathrm{a}}$ would increase by 19 and $20 \mathrm{~mm}$ respectively. However, because rainfall is very low, benefits are quite small.

Results of assessment of impacts of increased or decreased water table depths relative to present indicate that an appropriate regional management of the water table and protection of the groundwater to avoid its declining are paramount for the conservation of the Horqin landscape and ecosystems, and to further combat desertification in this fragile sandy area. Moreover, because the declining of the water table may induce farmers to irrigate by pumping from the groundwater, the only source of water in the area, it is important to underline that pumping will cause a further

Table 9

Impacts of changes in groundwater table level (WTL) on the seasonal groundwater contribution, actual evapotranspiration, actual transpiration and soil evaporation.

\begin{tabular}{|c|c|c|c|c|c|}
\hline \multicolumn{2}{|c|}{ Groundwater table depth scenarios } & \multirow{2}{*}{$\frac{\mathrm{GWC}(\mathrm{mm})}{216}$} & \multirow{2}{*}{$\frac{\mathrm{ET}_{\mathrm{c} \mathrm{act}}(\mathrm{mm})}{434}$} & \multirow{2}{*}{$\begin{array}{l}T_{\mathrm{a}}(\mathrm{mm}) \\
334\end{array}$} & \multirow{2}{*}{$\frac{E_{\mathrm{S}}(\mathrm{mm})}{104}$} \\
\hline High rainfall (363 mm) & Observed WTL & & & & \\
\hline & WTL -10 & 210 & 437 & 333 & 104 \\
\hline & $\mathrm{WTL}-20$ & 189 & 436 & 332 & 104 \\
\hline \multirow[t]{4}{*}{ Low rainfall (125 mm) } & Observed WTL & 185 & 360 & 300 & 60 \\
\hline & $\mathrm{WTL}+10$ & 208 & 379 & 320 & 60 \\
\hline & WTL -10 & 115 & 295 & 235 & 60 \\
\hline & $\mathrm{WTL}-20$ & 101 & 283 & 224 & 60 \\
\hline
\end{tabular}


lowering of the groundwater table, thus increasing the degradation of the ecosystems and the risks of desertification.

\section{Conclusions}

The SIMDualKc model, that adopts the dual crop coefficient approach, was successfully calibrated and validated for simulating capillary rise from the groundwater table using two contrasting maize crop seasons, with high and low rainfall and high and low water table depths. Hence, the study provided for a proper analysis of crop water use, soil water balance and groundwater contribution to water use by a groundwater dependent maize. Results show that using only two contrasting season data sets was enough to properly perform the desired GWC assessment and to appropriately compute the actual transpiration and soil evaporation using the FAO56 dual crop coefficient approach.

A good set of basal crop coefficients and evaporation and capillary rise parameters were then calibrated that allow further exploring the model to assess cropland water use and groundwater contribution in Horqin Sandy Area. Simulation results also show that using appropriately selected default parameters allows extending the use of SIMDualKc to other similar areas in Inner Mongolia.

Results for both crop seasons having different rainfall and contrasting water table depths show that groundwater contribution is extremely important, exceeding 50\% of actual crop evapotranspiration over the season and, in particular, during mid-season and late season when yield development and maturation occurs.

It was observed that the ratio of soil evaporation to evapotranspiration $\left(E_{\mathrm{S}} / \mathrm{ET}_{\mathrm{c} \text { act }}\right)$ was relatively small, $23 \%$ and $17 \%$ respectively for the water abundant and water deficit seasons, with the soil evaporation amount depending on rainfall because capillary rise does not contribute to $E_{s}$. Naturally, the amount of GWC highly relates with actual transpiration and being generally above $50 \%$ during mid- and late-season.

Results indicate that cropping in the area has a high failure risk when rainfall is low and the water table is relatively deep. To verify this assumption, simulations were performed for water table scenarios built from those observed. For the case of high rainfall and high water table, it was verified that changes in water table level produced relatively small changes in GWC, $\mathrm{ET}_{\mathrm{c}}$ act, and $T_{\mathrm{a}}$. Differently, lowering the WTL for the dry year having a low water table led to large decreases in GWC and, consequently in $\mathrm{ET}_{\mathrm{c} \text { act, }}$ and $T_{\mathrm{a}}$. The feasibility of cropping in Horqin if the water table declines becomes very low, particularly if rainfall is low. The risk of degradation of the ecosystems and landscape of Horqin would then increase. Therefore, appropriate regional management of the groundwater, including avoidance of pumping for irrigation, is required for conservation of the Horqin Sandy Land landscape and to further combat desertification in the area.

\section{Acknowledgements}

This study was supported by the National Natural Science Foundation of China, Contract \#51139002, \#51069005; the Chinese Ministry of Science and Technology, contract \#2010DFA71460; the Inner Mongolia Agricultural University Grant NDTD2010-6; and the Inner Mongolia Industrial Innovation Team, as well as LEAF - Landscape, Environment, Agriculture and Food, University of Lisbon, and the China-Portugal cooperative research programme.

\section{References}

Abi Saab, M.T., Todorovic, M., Albrizio, R., 2015. Comparing AquaCrop and CropSyst models in simulating barley growth and yield under different water and nitrogen regimes. Does calibration year influence the performance of crop growth models? Agric Water Manage. 147, 21-33.

Allen, R.G., Pereira, L.S., 2009. Estimating crop coefficients from fraction of ground cover and height. Irrig. Sci. 28, 17-34.

Allen, R.G., Pereira, L.S., Raes, D., Smith, M., 1998. Crop Evapotranspiration, Guidelines for Computing Crop Water Requirements. FAO Irrigation and Drainage Paper 56. FAO, Rome, Italy, pp. 300.

Allen, R.G., Pereira, L.S., Smith, M., Raes, D., Wright, J.L., 2005. FAO-56 dual crop coefficient method for estimating evaporation from soil and application extensions. J. Irrig. Drain. Eng. 131, 2-13.

Allen, R.G., Wright, J.L., Pruitt, W.O., Pereira, L.S., Jensen, M.E., 2007. Water requirements. In: Hoffman, G.J., Evans, R.G., Jensen, M.E., Martin, D.L., Elliot, R.L. (Eds.), Design and Operation of Farm Irrigation Systems. , 2nd ed. ASABE, St. Joseph, MI, pp. 208-288.

Allen, R.G., Pereira, L.S., Howell, T.A., Jensen, M.E., 2011. Evapotranspiration information reporting: I. Factors governing measurement accuracy. Agric. Water Manage. 98, 899-920.

Bagan, H., Takeuchi, W., Kinoshita, T., Bao, Y., Yamagata, Y., 2010. Land cover classification and change analysis in the Horqin Sandy land from 1975 to 2007. IEEE J. Sel. Top. Appl. Earth Observ. Remote Sens. 3 (2), 168-177.

Cholpankulov, E.D., Inchenkova, O.P., Paredes, P., Pereira, L.S., 2008. Cotton irrigation scheduling in Central Asia: model calibration and validation with consideration of groundwater contribution. Irrig. Drain. 57, 516-532.

Duan, L.M., Liu, T.X., Wang, X.X., Wang, G., Ma, L., Luo, Y.Y., 2011a. Spatio-temporal variations in soil moisture and physicochemical properties of a typical semiarid sand-meadow-desert landscape as influenced by land use. Hydrol. Earth Syst. Sci. $15,1865-1877$.

Duan, L., Liu, T., Wang, X., Luo, Y., Wang, W., Liu, X., 2011b. Water table fluctuation and its effects on vegetation in a semiarid environment. Hydrol. Earth Syst. Sci. Discuss. 8, 3271-3304

Gowing, J.W., Rose, D.A., Ghamarnia, H., 2009. The effect of salinity on water productivity of wheat under deficit irrigation above shallow groundwater. Agric. Water Manage. 96, 517-524

Kahlown, M.A., Ashraf, M., Zia-ul-Haq, 2005. Effect of shallow groundwater table on crop water requirements and crop yields. Agric. Water Manage. 76, 24-35.

Kottek, M., Grieser, J., Beck, C., Rudolf, B., Rubel, F., 2006. World Map of the Köppen-Geiger climate classification updated. Meteorol. Z. 15 (3), 259-263.

Kowalik, P.J., 2006. Drainage and capillary rise components in water balance of alluvial soils. Agric. Water Manage. 86, 206-211.

Li, Y.L., Cui, J.Y., Zhang, T.H., Zhao, H.L., 2003. Measurement of evapotranspiration of irrigated spring wheat and maize in a semi-arid region of north China. Agric. Water Manage. 61, 1-12.

Li, F.-R., Zhao, L.-Y., Zhang, H., Zhang, T.-H., Shirato, Y., 2004. Wind erosion and airborne dust deposition in farmland during spring in the Horqin Sandy Land of eastern Inner Mongolia, China. Soil Till. Res. 75, 121-130.

Liu, T., Luo, Y., 2011. Effects of shallow water tables on the water use and yield of winter wheat (Triticum aestivum L.) under rain-fed condition. Aust. J. Crop Sci. 5, 1692-1697.

Liu, Y., Pereira, L.S., Fernando, R.M., 2006. Fluxes through the bottom boundary of the root zone in silty soils: parametric approaches to estimate groundwater contribution and percolation. Agric. Water Manage. 84, 27-40.

Ma, L., Liu, T.-X., 2007. Relationship of plant ecotype with groundwater depth and soil moisture in Horqin Sandy Land. J. Desert Res. 27 (3), 391-396 (in Chinese)

Martins, J.D., Rodrigues, G.C., Paredes, P., Carlesso, R., Oliveira, Z.B., Knies, A., Petry, M.T., Pereira, L.S., 2013. Dual crop coefficients for full and deficit irrigated maize in southern Brazil: model calibration and validation for sprinkler and drip irrigation and mulched soil. Biosyst. Eng. 115, 291-310.

Moriasi, D.N., Arnold, J.G., Van Liew, M.W., Bingner, R.L., Harmel, R.D., Veith, T.L., 2007. Model evaluation guidelines for systematic quantification of accuracy in watershed simulations. Trans. ASABE 50 (3), 885-900.

Nash, J.E., Sutcliffe, J.V., 1970. River flow forecasting through conceptual models: Part 1. A discussion of principles. J. Hydrol. 10 (3), 282-290.

Paço, T.A., Pôças, I., Cunha, M., Silvestre, J.C., Santos, F.L., Paredes, P., Pereira, L.S., 2014. Evapotranspiration and crop coefficients for a super intensive olive orchard. An application of SIMDualKc and METRIC models using ground and satellite observations. J. Hydrol. 519, 2067-2080.

Paredes, P., Rodrigues, G.C., Alves, I., Pereira, L.S., 2014. Partitioning evapotranspiration, yield prediction and economic returns of maize under various irrigation management strategies. Agric. Water Manage. 135, 27-39.

Pereira, L.S., Cai, L.G., Hann, M.J., 2003. Farm water and soil management for improved water use in the North China Plain. Irrig. Drain. 52 (4), 299-317.

Pereira, L.S., Gonçalves, J.M., Dong, B., Mao, Z., Fang, S.X., 2007. Assessing basin irrigation and scheduling strategies for saving irrigation water and controlling salinity in the Upper Yellow River Basin, China. Agric. Water Manage. 93 (3), 109-122.

Ritchie,J.T., 1972. Model for predicting evaporation from a row crop with incomplete cover. Water Resour. Res. 8, 1204-1213.

Rosa, R.D., Paredes, P., Rodrigues, G.C., Alves, I., Fernando, R.M., Pereira, L.S., Allen, R.G., 2012a. Implementing the dual crop coefficient approach in interactive software: 1. Background and computational strategy. Agric. Water Manage. 103, $8-24$.

Rosa, R.D., Paredes, P., Rodrigues, G.C., Fernando, R.M., Alves, I., Pereira, L.S., Allen, R.G., 2012b. Implementing the dual crop coefficient approach in interactive software: 2. Model testing. Agric. Water Manage. 103, 62-77.

Sinclair, T.R., Seligman, N., 2000. Criteria for publishing papers on crop modelling. Field Crop. Res. 68, 165-172. 
Shi, X.-H., Li, C.-Y., Liu, T.-X., 2007. Analysis on spatial characteristics of soil water in marshland dune areas in Horqin Sandy Land. J. Desert Res. 27, 837-842 (in Chinese).

Soylu, M.E., Istanbulluoglu, E., Lenters, J.D., Wang, T., 2011. Quantifying the impact of groundwater depth on evapotranspiration in a semi-arid grassland region. Hydrol. Earth Syst. Sci. 15, 787-806.

Stulina, G., Cameira, M.R., Pereira, L.S., 2005. Using RZWQM to search improved practices for irrigated maize in Fergana, Uzbekistan. Agric. Water Manage. 77, 263-281.

Tamea, S., Laio, F., Ridolfi, L., D’Odorico, P., Rodriguez-Iturbe, I., 2009. Ecohydrology of groundwater-dependent ecosystems: 2. Stochastic soil moisture dynamics. Water Resour. Res. 45 (5), W05420, http://dx.doi.org/10.1029/2008WR007293, 13 pp.

Tang, X., Cui, J.-Y., Zhao, X.-Y., Yun, J.-Y., Lian, J., Wang, X.-Y., Li, Y.-Q., 2011. Characteristics of maize transpiration and soil evaporation in Horqin sand land. Pratacult. Sci. 28, 788-792 (in Chinese).

Vervoort, R.W., Van der Zee, SEAT.M., 2008. Simulating the effect of capillary flux on the soil water balance in a stochastic ecohydrological framework. Water Resour. Res. 44 (8), W08425, http://dx.doi.org/10.1029/2008WR006889, $15 \mathrm{pp}$.

Willmott, C.J., 1981. On the validation of models. Phys. Geogr. 2, 184-194.

Wright, J.L., 1982. New evapotranspiration crop coefficients. J. Irrig. Drain. - ASCE 108, 57-74.

Xu, X., Huang, G., Sun, C., Pereira, L.S., Ramos, T.B., Huang, Q., Hao, Y., 2013. Assessing the effects of water table depth on water use, soil salinity and wheat yield: searching for a target depth for irrigated areas in the upper Yellow River basin. Agric. Water Manage. 125, 46-60.
Yan, Y., Zhu, J., Yan, Q., Zheng, X., Song, L., 2014. Modeling shallow groundwater levels in Horqin Sandy Land, North China, using satellite-based remote sensing images. J. Appl. Remote Sens. 8 (1), http://dx.doi.org/10.1117/1.JRS.8.083647.

Zhang, Y., Zhao, S., 2003. Analysis of land use change in Horqin Sandy Land and its surrounding area during the past 15 years. J. Nat. Res. 18 (2), 174-181 (in Chinese).

Zhang, L., Liu, Z., Zhou, R., Zhai, S., 2009. Farmland expansion prediction at a pastora village in northeastern China: a spatially explicit targeting approach. Environ. Earth Sci. 59, 847-852.

Zhao, H.L., Zhou, R.L., Zhang, T.H., Zhao, X.Y., 2006. Effects of desertification on soi and crop growth properties in Horqin sandy cropland of Inner Mongolia, north China. Soil Till. Res. 87, 175-185.

Zhao, X.Y., Zhang, C.M., Zuo, X.A., Huang, G., Huang, Y.X., Luo, Y.Y., Wang, S.K., Qu, H., 2009. Challenge to the desertification reversion in Horqin Sandy Land. Chin. J. Appl. Ecol. 20 (7), 1559-1564 (in Chinese).

Zhao, N., Liu, Y., Cai, J.B., Paredes, P., Rosa, R.D., Pereira, L.S., 2013. Dual crop coefficient modelling applied to the winter wheat-summer maize crop sequence in North China Plain: basal crop coefficients and soil evaporation component. Agric. Water Manage. 117, 93-105.

Zheng, X., Zhu, J.J., Yan, Q.L., Song, L.N., 2012. Effects of land use changes on the groundwater table and the decline of Pinus sylvestris var. mongolica plantations in southern Horqin Sandy Land, Northeast China. Agric. Water Manage. 109, $94-106$.

Zuo, X., Zhao, X., Zhao, H., Zhang, T., Guo, Y., Li, Y., Huang, Y., 2009. Spatial heterogeneity of soil properties and vegetation-soil relationships following vegetation restoration of mobile dunes in Horqin Sandy Land, Northern China. Plant Soil 318, 153-167. 